\title{
Chinese Steel Enterprises' Strategies under the Pricing Model of Iron Ore in the World
}

\author{
Jiaqing Li \& Lihui Sun \\ School of Science Management \& Engineering Department, Qingdao University \\ 308 Ning Xia Road, Qingdao 266071, China \\ E-mail: lijiaqing84@126.com
}

\begin{abstract}
With the global non-renewable resources' shortage and prices rising, Chinese steel enterprises' production costs continue to grow. On the background of the global iron ore negotiation, the article analyzes the steel enterprise's vulnerable position in the iron ore negotiations and the influencing factors, and makes appropriate recommendations from the perspective of industry chain integration, in order to improve Chinese steel enterprises' bargaining power in the iron ore negotiation.
\end{abstract}

Keywords: Pricing model, Industrial chain, Negotiation, Bargaining power

\section{Introduction}

Since entering the 21 st century, with the rapid development of the Chinese economy, the domestic need for raw materials rapidly increases. As an import raw material for steel industry, the amount of iron ore used in the production has been increased explosively, and the foreign trade dependence ratio has surpassed $50 \%$. China has become the world's largest importer of iron ore resources, promotes the prosperity of the international trading market. However, as the largest buyer of resources, the Chinese steel enterprises are unable to grasp the initiative in the process of price negotiations, and have to endure the risk of out-of-control costs caused by the severe fluctuations in the prices of raw materials. The steel enterprises' profits have been continuously deprived, and the product price is also pushed up invisibly. With the promulgation of the relevant national policies, the industrial adjustment of the steel industry gradually emerges. how to improve our steel enterprise' bargaining position in the process of the iron ore' pricing, has attracted enough attention.

\section{The iron ore pricing model}

The annual iron ore price negotiations began in 1981, after the negotiation between the suppliers and the manufactures, it can confirm a price; once the price is determined, the two sides can execute it in a year. The negotiation practice is that any party of the supplier makes sure a price with any party of the manufactures, the negotiation is over. The suppliers and the manufactures must accept the price as the New Year's price, which is starting price. When the iron ore suppliers make a price with the first customer, they all promise that they won't make a lower price with he other steel enterprises; and the steel enterprises also promise so, don't accept a higher price with other mines. The European steel enterprises involved in the negotiations are as follows: Arcelor-Mittal, TKS, Tata-Corus, Riva; the Asia steel enterprises are Nipponsteel, JFE, POSCO, and BAOSTEEL

\section{Domestic market realities}

There are two iron ore's prices; one is long-HS price and the other is spot price. The spot price changes with the market, but the long-HS price is made at the beginning of a fiscal year, and has a long-term stability. The trading volume in the spot market is larger than in the long-HS market. The spot price is based on the long-HS price, and sometime is higher than the long-HS price. With the rising need for the iron ore, the long-HS price becomes higher and higher, that has seriously hampered china's iron and steel industry's health and orderly development.

\subsection{The iron ore import volume has risen steeply}

Figure 1 shows the change of all our countries' demand in 2000-2009 years. In this decade, the other industrial countries' demand is more or less flat, not changed very much, but From the chart we can see that the china's demand for iron ore has risen sharply, result in the rising of the global iron ore production. It can be seen, the global iron ore production increased, most are designed to meet china's rapid economic development.

\subsection{The source of iron ore is concentrated}

Showed in table 1, according to statistics from 1-10 month of 2008, the volume from Australia is about $41.2 \%$, 
from Brazil is $22.6 \%$, and from India is $20.4 \%$, from the above three countries, the imports volume is about $85 \%$ of the whole imports. The resources of the world's iron ore exports are basically monopolized by the three countries. In 2008 the first 10 months' import volume has also been close to the whole of 2007's import volume. We can see that the china's steel industry's requirement to the resources has maintained a growth trend, and the sources are relatively concentrated, as a result, provide convenience for the price's rise from the iron giants.

\subsection{Recent years' result of the iron ore price negotiations.}

Table 2 is the increase of the iron ore negotiated prices over the years. Because Asia is the largest market, the starting price is usually made in Asia. In 2007 and 2008 the world economy has experienced a big turn from the financial prosperous to crisis, and the price's change is very obvious. With the recovery of the world economy in 2009 , the demand for iron ore resources is back to the record level of historical terms. The price negotiation in 2010 is under the way, the industry insiders predict that the price may rise about $50 \%$.

\section{Affecting the pricing mechanism's factors analysis}

Chinese steel enterprises' weak position in the iron ore price negotiations is related to themselves strength on the one hand, on the other hand is also affected by the external market environment factors. The overtaking demand, monopoly market, confusion importer management and industry self-development problems, have all caused the negative impact on the iron ore price negotiations. Only if detailed analyze the influence by the each of the impact factor, we can sum up the response strategy.

\subsection{Market demand}

China's infrastructure construction and the expansion of railway network have brought the expansion of steel consumption, as an important raw material of steel, the market demand of iron ore will increase significantly. Foreign mining firms have seen huge demand for the china's market, on the one hand continue to increase production, and on the other hand continue to raise the prices of the iron ore. As a non-renewable resource, all countries expect the future scarcity of resources, so they push up the price of the global non-renewable resources. In this trend, the domestic steel enterprises have to bear too great iron ore price improved, and send hope to raise domestic prices of steel products in order to obtain profit, at last lost the country and people's wealth.

\subsection{Degree of monopoly seller}

$80 \%$ of the international iron ore resources are located in Brazil, Australia, and India. The three iron ore mining enterprises BHP Billiton, Rio Tinto, CVRD, nearly monopolize the global allocation of resources. As the largest iron ore producers, they monopolize the means of production, monopolize the trading market, monopolize the iron ore price as a monopolist, and obtain the monopoly profits. But as the largest iron ore buyer, steel enterprises have to buy the iron ore form the producers at expensive prices, in order to meet the growing domestic resource requirements.

\subsection{Bargaining power of buyers}

Negotiations over annual iron ore contact prices in china have stalled between BAOSTEEL and its suppliers, but BAOSTEEL didn't well represented the interests of many domestic steel enterprises, and china steel association's intervention also did not change the weak situation. One reason is that domestic enterprises are too scattered and don't form a unified industry organization, can't form a centripetal force in the negotiation process, and easily be destroyed one by one, that can invisibly weak the bargaining team's chips. The other hand, some domestic steel enterprises have a definite link with foreign consortia, and ignoring the actual needs of the other steel enterprises. In addition, the spot market price fluctuation will also affect the process of negotiation, such as hoarding good, malicious bid up spot prices are likely to undermine the buyer's bargaining power.

\subsection{Degree of industrial chain integration}

Competition in the market now is not simply a special market region, but rises to the whole industry chain's competition. A strong enterprise can take control of the core of the industrial chain link, integrating the entire chain of distribution of profits; don't care about a single link advantages and disadvantages. Most of china's iron and steel enterprises are in the production and processing sectors of the steel industry chain, have large technology gaps compared with multinational corporations, and not expand into other parts of the industry chain; the profit could easily be swallowed by other parts. The reason Japanese firms have been able to accept such a high price, first, they can share ore prices, can share revenue, and second, the added value of products and production efficiency is very high, the profit is very larger than china's.

\section{China's steel enterprises strategies}

When the global non-renewable resources attract national attention at the same time, the prices are invisible to 
rise slowly. As the necessary material for the steel production, the iron ore price volatility has also attracted the government's attention. As the biggest iron ore demand country, the large number of domestic steel enterprises, how to improve the iron ore pricing power, to get the expected results, to lower themselves production costs, and enhance to international competitiveness, has become the focus of recent public opinion.

\subsection{Expansion of the industry chain to enter the upstream raw material production processes}

Domestic steel enterprises should improve the efficiency of the domestic resource exploration and weaken the dependence on foreign resources; improve the steel enterprises and the mining enterprises' cooperative intensity, share the upstream part's profits in investments and shares, or obtain a satisfactory co-operation condition; take the initiative to acquire mining enterprises who have the development potential, providing funds or technical support to develop their own overseas energy base.

\subsection{Domestic price negotiations unified, global sourcing and procurement decentralization}

We should establishment a unified negotiation and trading mechanism, entrust to credible foreign traders to deliver the resources in unison, and the traders must reflect the fair and impartial principle, treat all the legitimate steel enterprises equally without discrimination. We should decentralize the global resources' purchase in order to avoid concentration in a mining enterprise, and reduce dependence on it. We should reasonably use the negotiating skills in different mining enterprises to make them restraint each other, in order to obtain a satisfactory transaction price.

\subsection{Implement the steel industry adjustment programs}

The Ministry of Industry and Information Technology is eliminating backward production capacity to promote the steel industry mergers and restructuring, adjust the pattern of existing steel enterprises, make strong-strong cooperation and promote the steel enterprise become bigger and stronger, thus boost the steel industry's health and flourish development. Rationally plan the regional distribution so that the steel enterprises from different regions can cooperation with each other, and improve industrial competitiveness together. With the national and regional revitalization, the steel industry should reasonably run the existing resource, promote the development of subsidiary industries.

\subsection{Integrate industry chain; upgrade the industry's overall superiority}

The future's competition is the competition in the industry chain; a single link can not survive in the competition. In improving their own R\&D and production technology, the steel enterprises should take participation in resource acquisition, logistic and transport, marketing and other related links, establish a long-term partnership with relevant enterprises. While mastering the core areas, they should ensure that the profit flow reasonable within the chain.

\section{Conclusions}

Improving Chinese steel enterprises' position in the iron ore negotiations is a representation that the steel enterprises enter the international market; get the redistribution rights of the global non-renewable resources. As the world's largest iron ore demander, Chinese steel enterprises should improve the competitiveness of products, obtain the rights of resources exploitation and material flow, in order to obtain the advantages of industrial chain integration, share the profits of different sectors, at the same time, obtain the legitimate rights as same as the other multinational corporation from the industrial chain. Only in this way, Chinese steel enterprises can keep their legs in the fierce global market competition, can create wealth for the country, and can maintain Chinese steel industry in the long-term healthy development.

\section{References}

Buitelaar, R.M., \& Padilla Perez, R. (2000). Maquila, economic reform and corporate strategies. World Development, 28(9), 1627-1642.

Gereffi, G. (1999). International trade and industrial upgrading in the apparel commodity chain. Journal of international Economics, 48(1), 37-70.

Humphrey, J., \& Schimitz, H. (2002). Developing Country Firms in the World Economy: Governance and Upgrading in global Chains. INEF Report 61/2002. Duisburg; INEF-University of Duisburg, 2002.

Schmitz, H. (2000). Local upgrading in global chains. Presented at the international conference, Local Production Systems and New Industrial Policies. Rio de Janeiro, Brazil, September. 
Table 1. The main source of china's imports of iron ore, the quantity and the proportion in the past two years

\begin{tabular}{|c|c|c|c|}
\hline $\begin{array}{c}\text { Source of iron ore } \\
\text { imports }\end{array}$ & $\begin{array}{c}\text { 2008 imports from } \\
\text { January to October }\end{array}$ & Proportion & 2007 annual volume \\
\hline China's total imports & 37669 & & 38309 \\
\hline Australia & 15535 & $41.2 \%$ & 14560 \\
\hline Brazil & 8526 & $22.6 \%$ & 9763 \\
\hline India & 7676 & $20.4 \%$ & 7937 \\
\hline South Africa & 1217 & $3.2 \%$ & 1223 \\
\hline Ukraine & 627 & $1.7 \%$ & 228 \\
\hline Indonesia & 598 & $1.6 \%$ & 442 \\
\hline Iran & 489 & $1.3 \%$ & 504 \\
\hline
\end{tabular}

Table 2. The iron ore negotiated prices over the years

\begin{tabular}{|c|c|c|c|c|c|}
\hline \multirow{2}{*}{ Year } & \multirow{2}{*}{$\begin{array}{c}\text { The time reaching an } \\
\text { agreement }\end{array}$} & \multicolumn{2}{|c|}{ Negotiators } & \multicolumn{2}{|c|}{ Price growing } \\
\hline & & Buyers & Providers & Fine ore & Lump ore \\
\hline 2009 & 2009.8 & BAOSTEEL & FMG & $-35.02 \%$ & $-50.42 \%$ \\
\hline 2009 & 2009.5 & NSC & TINTO & $-33 \%$ & $-44 \%$ \\
\hline & 2008.1 & BAOSTEEL & TINTO & $79.88 \%$ & $96.5 \%$ \\
\hline 2008 & 2007.3 & $\begin{array}{c}\text { NSC } \\
\text { POHANG }\end{array}$ & CVRD & $65 \%$ & $71 \%$ \\
\hline 2007 & 2006.12 & BAOSTEEL & CVRD & $9.5 \%$ & $9.5 \%$ \\
\hline 2006 & 2006.6 & BAOSTEEL & BHP & $19 \%$ & $19 \%$ \\
\hline 2005 & 2005.2 & NSC & TINTO & $71.5 \%$ & $71.5 \%$ \\
\hline
\end{tabular}

$\square$ i mport vol ume of chi na (mili on ton)

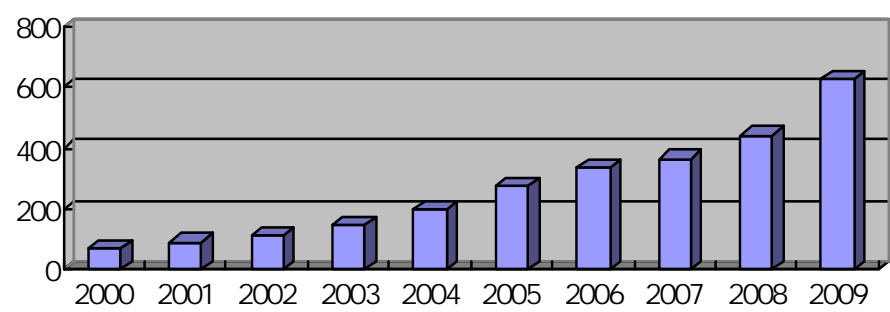

Figure 1. The iron ore import volume of china in the past years 